Pedagogik Jurnal Pendidikan, Maret 2014, Volume 9 Nomor 1, (39-45)

\title{
PENGARUH LAYANAN BIMBINGAN BELAJAR TERHADAP MOTIVASI BELAJAR PESERTA DIDIK DI MTs MUSLIMAT NU PALANGKARAYA
}

\author{
Oleh : Mudzalifah Mayasari * dan M. Fatchurahman **
}

\begin{abstract}
Abstrak
Penelitian ini bertujuan untuk mengetahui pengaruh antara Layanan Bimbingan Belajar yang diterima peserta terhadap Motivasi Belajar di sekolah pada kelas VIII MTs Muslimat NU Palangkaraya tahun pelajaran 2013/2014.

Metode yang digunakan dalam penelitian ini menggunakan metode deskriptif yaitu penelitian yang memaparkan tentang karakteristik dari data variabel yang diteliti. Populasi dan sampel dalam penelitian ini adalah peserta didik kelas VIII MTs Muslimat NU Palangkaraya tahun pelajaran 2013/2014 dengan jumlah 54 orang. Teknik pengambilan sampel menggunakan teknik sampel random atau sampel acak.instrumen yang digunakan dalam penelitian ini adalah angket yang terdiri dari masing-masing variabel 25 item.

Berdasarkan hasil penelitian variabel layanan bimbingan belajar terhadap motivasi belajar dengan menggunakan analis statistik korelasi product moment tangkar, diperoleh $\mathrm{r}$ hitung sebesar $=$ $0,55>\mathrm{r}$ tabel $(\mathrm{N}=54-2)$ pada taraf signifikan 5\% tabel $\mathrm{r}$ produk moment, yaitu 0,279. Mengingat $\mathrm{r}$ hitung lebih lebih besar dari $r$ teoretik maka disimpulkan terdapat pengaruh/ hubungan yang positif atau signifikan antara layanan bimbingan belajar dengan motivasi belajar.
\end{abstract}

\section{Kata Kunci : Layanan Bimbingan Belajar, Motivasi Belajar}

\section{PENDAHULUAN}

Bimbingan belajar dewasa ini telah menjadi salah satu pelayanan pendidikan yang sangat dirasakan keperluan dan urgensinya di sekolah. Indonesia telah mengambil langkah-langkah yang diperlukan untuk memasukkan program bimbingan konseling sebagai salah satu bidang penting dalam program sekolah yang bertujuan membimbing untuk membantu siswa menyelesaikan masalahmasalah pendidikan dan jurusan yang dipilih. Asmani (2010) mendefinisikan bahwa "bimbingan adalah proses pemberian bantuan yang dilakukan oleh seorang ahli kepada individu dengan menggunakan berbagai prosedur, cara dan bahan agar individu tersebut mampu mandiri dalam memecahkan masalahmasalah yang dihadapinya".

Bimbingan merupakan salah satu komponen yang penting dalam proses pendidikan sebagai suatu sistem. Bimbingan merupakan bantuan kepada individu dalam menghadapi persoalanpersoalan yang dapat timbul dalam hidupnya. Bantuan semacam itu sangat tepat jika diberikan di sekolah, supaya setiap peserta didik lebih berkembang ke arah yang semaksimal mungkin. Oleh karena itu, bimbingan menjadi bidang layanan khusus dalam keseluruhan kegiatan pendidikan sekolah yang ditangani oleh tenaga-tenaga ahli dalam bidang tersebut.

Adapun diantara layanan-layanan bimbingan yang diselenggarakan di sekolah salah satunya adalah layanan bimbingan belajar. Layanan tersebut akan sangat membantu peserta didik dalam menggembangkan dirinya mengenai sikap dan kebiasaan belajarnya dengan baik, mengenai materi belajar yang cocok dengan kecepatan dan kesulitan belajarnya, serta mengenai berbagai aspek tujuan dan

* Mudzalifah Mayasari Mahasiswa FKIP Universitas Muhammadiyah Palangkaraya

**Drs. M. Fatchurahman, M.Pd Dosen FKIP Universitas Muhammadiyah Palangkaraya 
kegiatan belajarnya. Prayitno (1997) mengatakan bahwa Layanan bimbingan belajar dimaksudkan untuk memungkinkan siswa memahami dan mengembangkan sikap dan kebiasaan belajar yang baik, keterampilan dan materi belajar yang cocok dengan kecepatan dan kesulitan belajarnya, serta tuntutan kemampuan yang berguna dalam kehidupan dan perkembangan dirinya. Selanjutnya Prayitno (1997) menambahkan bhawa Materi umum yang dapat diangkat melalui layanan pembelajaran ada berbagai macam, yaitu meliputi : a) Pengenalan siswa yang mengalami masalah belajar tentang kemampuan, motivasi, sikap dan kebiasaan belajar. b) Pengembangan motivasi, sikap dan kebiasaan belajar yang baik. c) Pengembangan keterampilan belajar : membaca, mencatat, bertanya dan menjawab, dan menulis. d) Pengajaran perbaikan e) Program pengayaan.

Dengan demikian peran layanan bimbingan belajar sangat diperlukan dalam membantu meningkatkan motivasi belajar yang ada pada peserta didik, agar peserta didik dapat memiliki motivasi yang tinggi dalam belajar baik di rumah maupun disekolah dan dapat meraih prestasi yang lebih baik. Belajar tidak terlepas dari motivasi karena sebagai daya upaya yang mendorong seseorang untuk melakukan sesuatu. Sardiman (2006) motif merupakan daya penggerak dari dalam untuk melakukan kegaiatan untuk mencapai tujuan. Dalam belajar motivasi sangat diperlukan agar ada daya penggerak didalam diri peserta didik yang menimbulkan kegiatan belajar, menjamin kelangsungan dan memberikan arah pada kegiatan belajar sehingga tujuan yang dikehendaki dapat tercapai.

Penelitian Setianingsih (2009) tentang Peranan Layanan Bimbingan dan Konseling terhadap Peningkatan Motivasi Belajar Siswa di SMA Muhammadiyah 2 Yogyakarta, menunjukkan bahwa peranan layanan BK dalam meningkatkan motivasi belajar siswa adalah dengan cara memberikan layanan bimbingan klasikal mengenai masalah belajar, pelayanan orientasi, layanan informasi, layanan konseling individu dan kelompok, bimbingan teman sebaya, layanan, mediasi, pelayanan pengambilan data yang berhubungan dengan masalah dan hasil belajar siswa, mengadakan kerjasama dengan guru bidang studi dan wali kelas, kerjasama dengan orang tua siswa, konferensi kasus dan kunjungan rumah. Sedangkan yang menjadi faktor pendukung dalam meningkatkan motivasi belajar siswa adalah adanya materi bimbingan, fasilitas sekolah dan koordinasi dengan orang tua. Faktor penghambatnya adalah lingkungan luar sekolah, banyaknya siswa dan latar belakang siswa yang beragam dan kurangnya jam BK

Dalam motivasi belajar dorongan merupakan kekuatan mental untuk melakukan kegiatan dalam rangka pemenuhan harapan dan dorongan dalam hal ini adalah pencapaian tujuan. Kemudian Sardiman (2006) motivasi pada diri seseorang itu memiliki ciri-ciri : tekun menghadapi tugas, ulet menghadapi kesulitan (tidak lekas putus asa), menunjukkan minat terhadap bermacammacam masalah, lebih senang bekerja mandiri, tidak cepat bosan terhadap tugastugas yang rutin, dapat mempertahankan pendapatnya, tidak cepat menyerah terhadap hal yang diyakini, senang mencari dan memecahkan masalah soal-soal.

Apabila seseorang mempunyai ciriciri tersebut, berarti peserta didik mempunyai motivasi yang cukup kuat. Kegiatan belajar mengajar akan berhasil 
dengan baik jika peserta didik memiliki motivasi dan minat untuk belajar seperti, tekun dalam mengerjakan tugas, senang memecahkan soal-soal, ulet dalam mengatasi kesulitan belajar, bahkan lebih lanjut peserta didik lebih peka dan responsif terhadap berbagai masalah umum dan bagaimana memikirkan pemecahannya. Peranan motivasi sangat penting dalam belajar. Banyak peserta didik dengan intelegensi yang rendah disebabkan tidak adanya motivasi dalam belajar. Fungsi motivasi yang seharusnya sebagai pedorong, penggerak, dan pengarah perbuatan belajar tidak diperankan dengan baik.

Berdasarkan informasi yang diperoleh dari guru bimbingan konseling dan para wali kelas VIII di MTs Muslimat NU Palangkaraya tahun pelajaran 2013/2014 terdapat sekitar $40 \%$ peserta didik kelas VIII yang kurang adanya motivasi dalam belajar, seperti kurang semangat dan hanya santai-santai bahkan melamun sendiri waktu mengikuti pelajaran, memainkan handphone, malas mengerjakan tugas, coret-coret kertas atau buku dengan coretcoretan yang tidak jelas, atau hanya asyik ngobrol dengan teman disampingnya ketika guru mengajar maupun ketika guru memberikan tugas sehingga mengganggu proses belajar mengajar disekolah tersebut. Berdasarkan fenomena tersebut di atas, maka penelitian ini bertujuan untuk mengetahui ada atau tidak adanya pengaruh layanan bimbingan belajar terhadap motivasi belajar peserta didik kelas VIII di MTs Muslimat NU Palangkaraya.

\section{METODOLOGI PENELITIAN}

Penelitian ini dilaksanakan pada bulan September sampai Desember 2013 pada MTs Muslimat NU Kecamatan Pahandut Kota Palangkaraya. Pendekatan yang digunakan dalam penelitian ini adalah pendekatan kuantitatif. Sedangkan populasi dalam penelitian ini adalah peserta didik kelas VIII MTs Muslimat NU Palangkaraya dengan jumlah 108 orang dengan sampel seluruh populasi. Data diperoleh melalui angket. Angket dalam penelitian ini tidak dilakukan uji coba instrument untuk memenuhi validitas empiris, tetapi dilakukan uji validitas teoritis dengan cara: (1) menyusun kisi-kisi instrument agar angket sesuai dengan indikator variable (2) judging expert, yaitu dilakukan dengan cara mengkonsultasikan istrumen dengan ahlinya (3) menelaah kembali hasil data yang terkumpul dari instrument tersebut (respondennya). Sebelum dilakukan analisis data, terlebih dahulu dilakukan pengujian persyaratan analisis data yang diperoleh. Persyaratan yang harus dipenuhi yaitu uji normalitas dan uji linieritas.

Sedangkan analisis data yang digunakan adalah Korelasi Momen Tangkar dari Pearson. Selanjutnya untuk menguji hasil perhitungan $r_{x y}$ apakah signifikan atau tidak, maka konsultasikan dengan tabel $r$ teoretik dengan $\mathrm{N}-2$ atau derajat kebebasan $\mathrm{db}=\mathrm{N}-2$ pada taraf signifikan 5\%. Apabila harga $\mathrm{r}_{\mathrm{xy}}$ yang diperoleh melalui perhitungan lebih besar atau sama dengan $r$ tabel, maka variabel tersebut berpengaruh positif/signifikan, sebaliknya jika harga $r_{x y}$ perhitungan lebih kecil dari $\mathrm{r}$ tabel, maka variabel tersebut berpengaruh negatif/tidak signifikan.

\section{HASIL DAN PEMBAHASAN}

Berdasarkan perhitungan atas tabulasi kerja variabel layanan bimbingan belajar, dapat dikemukakan bahwa nilai (skor) statistik minimum 49 dan maksimum 74 atau rata-rata mean sebesar 59,3. Untuk mendeskripsikan kategori layanan bimbingan belajar dibedakan menjadi tiga 
kategori yaitu tinggi, sedang dan rendah. Penentuan kategori tersebut didasarkan atas besarnya simpangan baku ideal dan skor rerata ideal. Rumus mean ideal adalah $1 / 2$ (skor tertinggi ideal + skor terendah ideal), dan untuk simpangan baku ideal (SD) digunakan rumus $1 / 6$ ( skor tertinggi ideal skor terendah ideal). Penggolongan tersebut adalah : (1) Kategori baik $=(\mathrm{X}+1 \mathrm{SD})-(\mathrm{X}$ $+3 \mathrm{SD})$. (2) Kategori sedang $=(\mathrm{X}-1 \mathrm{SD})-$ $(\mathrm{X}+1 \mathrm{SD})$. (3) Kategori rendah $=(\mathrm{X}-$ 3SD) - (X - 1SD) (Sutrisno Hadi, 1987).
Variabel layanan bimbingan belajar dalam penelitian ini diungkap dengan menggunakan angket yang terdiri dari 25 butir pertanyaan yang masing-masing option jawaban diberi skor 1 sampai dengan 4, sehingga akan diperoleh skor ideal tertinggi 100 dan skor ideal terendah 25 . Dengan demikian diperoleh harga mean ideal 62,5 dan harga SD ideal 12,5. Berdasarkan nilai tersebut maka klasifikasi penggolongan variabel layanan bimbingan konseling belajar dapat dilihat pada tabel berikut.

Tabel 1

Klasifikasi Layanan Bimbingan Belajar

\begin{tabular}{|c|r|r|c|}
\hline Interval klas & Frekuensi & Persentase & Kategori \\
\hline & & & \\
$76-10$ & 0 & $0,00 \%$ & Baik \\
$51-75$ & 49 & $90,74 \%$ & Sedang \\
$25-50$ & 5 & $9,26 \%$ & Rendah \\
\hline
\end{tabular}

Berdasarkan rerata yang diperoleh sebesar 59,3 dan pengkategorian seperti tabel tersebut di atas, maka layanan bimbingan konseling belajar dalam penelitian ini terkategori sedang.

Sedangkan berdasarkan tabulasi kerja motivasi belajar, dapat dikemukakan bahwa nilai (skor) statistik minimum 48 dan maksimum 71 atau diperoleh rata-rata (Mean) sebesar 59,22 dan standar deviasi (SD) 5,71. Untuk mendeskripsikan kategori motivasi belajar dibedakan menjadi tiga kategori yaitu baik, sedang dan rendah. Penentuan kategori tersebut didasarkan atas besarnya simpangan baku ideal dan skor rerata ideal. Rumus mean ideal adalah $1 / 2$ (skor tertinggi ideal + skor terendah ideal), dan untuk simpangan baku ideal (SD) digunakan rumus $1 / 6$ ( skor tertinggi ideal skor terendah ideal). Variabel motivasi belajar dalam penelitian ini diungkap dengan menggunakan angket yang terdiri dari 25 butir pertanyaan yang masingmasing option jawaban diberi skor 1 sampai dengan 4, sehingga akan diperoleh skor ideal tertinggi 100 dan skor ideal terendah 25. Dengan demikian diperoleh harga mean ideal 62,5 dan harga SD ideal 12,5. Berdasarkan nilai tersebut maka klasifikasi penggolongan variabel layanan bimbingan konseling belajar dapat dilihat pada tabel berikut. 
Pedagogik Jurnal Pendidikan, Maret 2014, Volume 9 Nomor 1, (39-45)

Tabel 2

Klasifikasi Motivasi Belajar

\begin{tabular}{|c|r|r|c|}
\hline Interval klas & Frekuensi & Persentase & Kategori \\
\hline & & & \\
$76-10$ & 0 & $0,00 \%$ & Baik \\
$51-75$ & 51 & $94,44 \%$ & Sedang \\
$25-50$ & 3 & $5,56 \%$ & Rendah \\
\hline
\end{tabular}

Dilihat dari kriteria motivasi belajar dengan rata-rata 59,22 serta pengkategorian sebagaimana tabel di atas, maka motivasi belajar dalam kategori ini termasuk kategori sedang.

Sedangkan hasil pengujian hipotesis pengaruh antara variabel layanan bimbingan belajar $(\mathrm{X})$ terhadap motivasi belajar peserta didik ( $\mathrm{Y}$ ) diperoleh $\mathrm{r}$ hitung $=0,55>\mathrm{r}$ tabel $(\mathrm{N}=54-2)$ pada taraf signifikan 5\% tabel $\mathrm{r}$ produk moment, yaitu 0,279 maka kedua variabel tersebut terdapat pengaruh yang signifikan sebesar 0,271.

Dengan demikian secara keseluruhan setelah dilakukan analisis data variabel layanan bimbingan belajar terhadap motivasi belajar dengan menggunakan analisis statistik korelasi momen tangkar, diperoleh $r$ hitung sebesar $=0,55>\mathrm{r}$ tabel $(\mathrm{N}=54)$ pada taraf signifikan 5\% tabel $\mathrm{r}$ produk moment, yaitu 0,279. Mengingat $r$ hitung lebih lebih besar dari $r$ teoretik maka disimpulkan terdapat pengaruh yang positif atau signifikan sebesar 0,271 antara layanan bimbingan belajar dengan motivasi belajar. Hal tersebut berarti bahwa semakin tinggi layanan bimbingan belajar yang diberikan maka akan semakin tinggi pula motivasi belajar peserta didik, dan sebaliknya, semakin rendah layanan bimbingan belajar yang diberikan maka akan semakin rendah pula motivasi belajar peserta didik.

Hasil penelitian Qoyyimah (2012) tentang Peran Layanan Bimbingan Belajar dalam meningkatkan Prestasi Belajar Matematika pada anak Tunagrahita Ringan di Sekolah Luar Biasa Negeri Gedangan Sidoarjo, menunjukkan bahwa proses layanan bimbingan belajar bagi siswa tunagrahita ringan yang dilakukan di SLB Negeri Gedangan Sidoarjo sudah berjalan sesuai dengan program bimbingan dan konseling. Upaya bimbingan konseling dalam meningkatkan prestasi belajar matematika siswa kelas VIII-A adalah melalui metode teknik congklak, Adapun pelaksanaannya guru bimbingan dan konseling dibantu guru mata pelajaran matematika, melalui upaya tersebut diharapkan siswa tunagrahita ringan dapat meningkatkan prestasi belajar terutama pada bidang akademik matematika.

Demikian pula penelitian Setianingsih (2009) tentang Peranan Layanan Bimbingan dan Konseling terhadap Peningkatan Motivasi Belajar Siswa Di SMA Muhammadiyah 2 Yogyakarta menyimpulkan bahwa Peranan layanan BK dalam meningkatkan motivasi belajar siswa adalah dengan cara memberikan layanan bimbingan klasikal mengenai masalah belajar, pelayanan orientasi, layanan informasi, layanan konseling individu dan kelompok, bimbingan teman sebaya, layanan mediasi, pelayanan pengambilan data yang berhubungan dengan masalah dan hasil belajar siswa, mengadakan kerjasama dengan guru bidang studi dan wali kelas,

* Mudzalifah Mayasari Mahasiswa FKIP Universitas Muhammadiyah Palangkaraya

**Drs. M. Fatchurahman, M.Pd Dosen FKIP Universitas Muhammadiyah Palangkaraya 
kerjasama dengan orang tua siswa, konferensi kasus dan kunjungan rumah berjalan dengan baik dan hasilnya meningkat.

\section{KESIMPULAN.}

Berdasarkan hasil analisis statistik yang telah dilakukan, maka penelitian ini dapat disimpulkan, terdapat pengaruh yang positif atau signifikan sebesar 0,271 antara layanan bimbingan belajar dengan motivasi belajar peserta didik kelas VIII MTs Muslimat NU Palangkaraya tahun pelajaran 2013/2014, karena diperoleh $\mathrm{r}$ hitung $=0,55>\mathrm{r}$ tabel $(\mathrm{N}=$ 54-2) pada taraf signifikan $5 \%$ tabel $\mathrm{r}$ produk moment, yaitu 0,279. Itu berarti bahwa semakin tinggi layanan bimbingan belajar maka semakin tinggi pula motivasi belajar peserta didik, dan sebaliknya, semakin rendah layanan bimbingan konseling belajar maka semakin rendah pula motivasi belajar peserta didik.

Dari hasil penelitian tersebut disarankan kepada (1) kepala sekolah hendaknya lebih mengembangkan program sekolah khususnya yang berkaitan dengan peningkatan motivasi belajar. (2) guru bimbingan konseling hendaknya lebih meningkatkan pemberian layanan bimbingan belajar pada peserta didik agar peserta didik lebih meningkatkan motivasi belajarnya (3) guru mata pelajaran hendaknya tetap meningkatkan partisipasinya terhadap guru bimbingan konseling dalam meningkatkan pemberian layanan bimbingan belajar dalam meningkatkan motivasi belajar peserta didik

\section{DAFTAR PUSTAKA}

Dewa Ketut Sukardi, Drs, (2000) Pengantar Pelaksanaan Program Bimbingan dan Konseling di Sekolah. Jakarta : PT. Rineka Cipta

Hariyanto,S.Pd, (2013) Pengertian Motivasi Belajar. http://www.belajarpsikologi.com/pengertian-motivasi-belajar (23 Pebruari 2013)

Asmani, J.M. (2010) Panduan Efektif Bimbingan dan Konseling di Sekolah. Jogjakarta : Diva Press

Marlianti, (2012) Kebiasaan Belajar Peserta Didik Kelas VII dan VIII di MTs Muslimat NU Palangka Raya Tahun Pelajaran 2012/2013. Palangka Raya: Universitas Muhammadiyah Palangka Raya

Masri Singarimbun, (1982) Metodologi Penelitian Survey Sosial. Jakarta : LP3ES

Muhibbin Syah, (2000) Psikologi Pendidikan dengan Pendekatan Baru. Bandung: PT. Remaja Rosdakarya

Nana Sudjana, (2002) Metodologi Penelitian. Bandung : Tarsito

Prayitno, (1997) Layanan Bimbingan dan Konseling. Jakarta : Depdiknas

Sardiman,A.M, (2006) Interaksi dan Motivasi Belajar Mengajar. Jakarta: Grafindo.

Sofyan S.Willis, (2004) Konseling Individual Teori dan Praktek. Bandung : Alfabeta

Mutmainah Setianingsih NIM. 05470042, (2009) Peranan Layanan Bimbingan dan Konseling Terhadap Peningkatan Motivasi Belajar Siswa di SMA Muhammadiyah 2 Yogyakarta (Studi Kasus Mata Pelajaran Tarikh). Skripsi Thesis, Uin Sunan Kalijaga Yogyakarta.

Sugiyono, (2008) Metode Penelitian Pendidikan Pendekatan Kuantitatif dan Kualitatif R\&D. Bandung: Alfabeta

* Mudzalifah Mayasari Mahasiswa FKIP Universitas Muhammadiyah Palangkaraya

**Drs. M. Fatchurahman, M.Pd Dosen FKIP Universitas Muhammadiyah Palangkaraya 
Pedagogik Jurnal Pendidikan, Maret 2014, Volume 9 Nomor 1, (39-45)

Sugiyono, (2010) Metode penelitian Pendidikan Pendekatan Kuantitatif dan Kualitatif R\&D. Bandung: Alfabeta

Suharsimi Arikunto, (2006) Prosedur Penelitian Suatu Pendekatan Praktik. Jakarta : PT. Rineka Cipta

Sutrisno Hadi, (1987) Analisis Regresi. Yogyakarta : Andi Offset

Sutrisno Hadi, (1990) Statistik Jilid II. Yogyakarta : Fakultas Psikologi UGM

Sutrisno Hadi, (1994) Metodologi Researc III. Yogyakarta: Fakultas Psikologi UGM

Syaiful Bahri Djamarah, (2002) Psikologi Belajar. Jakarta : PT. Rineka Cipta 